\title{
Acute osteoarthritis: exuberant presentation of an unusual condition in the neonatal period
}

\author{
Rita Espírito Santo, ${ }^{1}$ Margarida Alcafache, ${ }^{2}$ Ana Tavares, ${ }^{3}$ \\ Maria Rosário Cancella de Abreu $^{3}$
}

${ }^{1}$ Pediatrics Department, Hospital de Santa Maria Lisboa, Portugal

${ }^{2}$ Pediatrics Department, Hospital Dona EstefâniaCentro Hospitalar Lisboa Central EPE, Lisboa, Portugal ${ }^{3}$ Neonatology Functional Unit, Woman and Children Department, Hospital de Cascais Dr. José de Almeida Lisboa, Portugal

\section{Correspondence to} Dr Rita Espírito Santo, a.r.espiritosanto@gmail.com

Accepted 4 September 2016

CrossMark

To cite: Espírito Santo $R$ Alcafache M, Tavares A, et al. BMJ Case Rep Published online: [please include Day Month Year doi:10.1136/bcr-2016215904

\section{DESCRIPTION}

A late preterm infant, with very low birth weight $(1430 \mathrm{~g})$, was admitted in our unit after an induced delivery at 34th week of gestation for fetal growth restriction since the 32nd week. After birth, the neonate's first evaluation revealed no infectious parameters $(9120 / \mu \mathrm{L}$ leucocytes, $\mathrm{C}$ reactive protein $(\mathrm{CPR})<0.5 \mathrm{mg} / \mathrm{dL}$ ) and no infection (including TORCH group) was documented in the mother during pregnancy. Between days 2 and 3 a peripheral venous catheter in the left inferior limb was used for fluid and electrolyte therapy. On day 7, left knee inflammation and pseudoparalysis were observed, with preferential position of limb in flexion (figure 1). No systemic signs were detected and laboratory evaluation showed normal leucocyte count and mild CPR elevation $(2.4 \mathrm{mg} / \mathrm{dL})$; the knee X-ray revealed soft tissue swelling and femur lytic lesion (figure 2); the joint ultrasound scan revealed synovial thickening with non-pure articular liquid. Surgical drainage was performed and empiric antibiotic therapy (vancomycin, gentamicin, cefotaxime) was started. After Staphylococcus aureus methicillin-sensitive isolation in blood and synovial fluid cultures, the therapy was changed to flucloxacillin. Thirty five days of antibiotics were completed with good response, without sequelae at follow-up 9 months later.

Acute osteoarthritis is an uncommon condition in neonates, usually presenting only systemic signs such as irritability, poor feeding or fever, therefore leading to delayed diagnosis. ${ }^{1}$ On the contrary, our case was manifested by local signs without any systemic repercussion. Concomitant septic arthritis and long-term complications are frequent. ${ }^{1}$ Early diagnosis and treatment are associated with better outcomes ${ }^{2}$ which were possible in our case due to exuberant local signs.

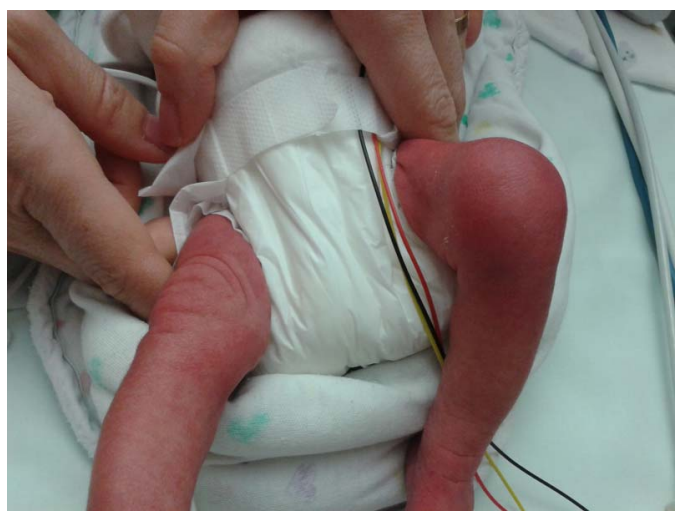

Figure 1 Exuberant signs of inflammation of the knee on the first day of disease.

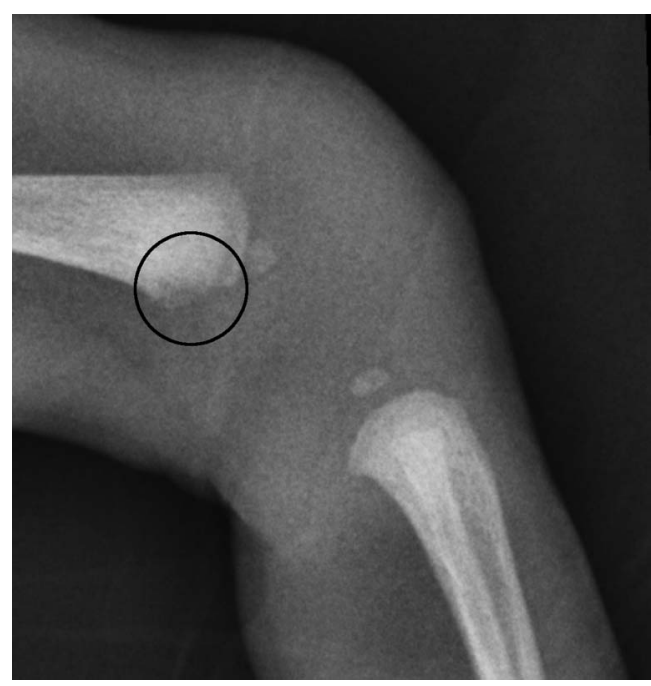

Figure 2 Knee radiograph: swelling of the soft tissues and femur lytic lesion.

\section{Learning points}

- Osteoarticular infections are uncommon in the neonatal period (1-3 per 1000 admissions in neonatal intensive care unit), usually presenting few symptoms. Nevertheless, the absence of systemic signs should not rule out infection in the newborn. ${ }^{12}$

- A daily minucious multiorganic clinical evaluation in all hospitalised neonates is essential for the diagnosis and prognosis, as an early surgical drainage and adequate antibiotics are associated with better outcomes. ${ }^{3}$

Contributors MA, AT, MRCdA conducted the analysis of the described case. RES and MA drafted the manuscript. AT and MRCdA critically reviewed the manuscript. All authors read and approved the final version.

Competing interests None declared.

Patient consent Obtained.

Provenance and peer review Not commissioned; externally peer reviewed.

\section{REFERENCES}

Korakaki E, Aligizakis A, Manoura A, et al. Methicillin-resistant Staphylococcus aureus osteomyelitis and septic arthritis in neonates: diagnosis and management. Jpn J Infect Dis 2007:60:129-31.

2 Softić I, Šadić S, Čustović S, et al. Septic arthritis in a ten day old newborn: how long to wait for articular drainage? Pediatr Today 2014; 10:51-4

3 Berberian G, Firpo V, Soto A, et al. Osteoarthritis in the neonate: risk factors and outcome. Braz J Infect Dis 2010;14:413-18. 
Copyright 2016 BMJ Publishing Group. All rights reserved. For permission to reuse any of this content visit http://group.bmj.com/group/rights-licensing/permissions.

BMJ Case Report Fellows may re-use this article for personal use and teaching without any further permission.

Become a Fellow of BMJ Case Reports today and you can:

- Submit as many cases as you like

- Enjoy fast sympathetic peer review and rapid publication of accepted articles

- Access all the published articles

- Re-use any of the published material for personal use and teaching without further permission

For information on Institutional Fellowships contact consortiasales@bmjgroup.com

Visit casereports.bmj.com for more articles like this and to become a Fellow 